\title{
A time to celebrate
}

\author{
By Linda K. Wallace
}

\section{This year's National Library Week is April 9-15}

$\mathbf{N}$ ational Library Week (NLW), coming up April 9-15, is our national holiday - a time to celebrate the life-changing contributions of all our nation's libraries-public, school, and academic. Here are some ideas to help you celebrate this annual event.

\section{What you can do}

- Be a library advocate. Join your state's delegation to Library Legislative Day on Capitol Hill on May 9. Write letters to your elected officials or local newspaper to urge support for library and information issues. Involve other faculty, administrators, and students in speaking out on behalf of libraries (see "Pass a Buck" on page 79).

- Join the chorus. Advertisers know it takes seven impressions to have a message remembered. ALA's national theme--"Libraries Change Lives" - is an opportunity for librarians to have greater impact by focusing on a single, powerful message. ALA Graphics offers a full line of posters and other promotional materials such as "Libraries Change Lives" quote cards to send as invitations to a reception or other spe-

\section{Apply for the NLW grant}

Plan now to apply for the 1995 Grolier National Library Week Grant. The grant of $\$ 2,000$ is awarded annually to the best proposal for a public awareness campaign tied to the theme and goals of National Library Week. The deadline is October 10, 1995. For guidelines and application form, contact the ALA Public Information Office, 50 E. Huron St., Chicago, IL 60611; phone: (800) 545-2433 ext. 5044. cial event at the library. The campaign tip sheet includes sample media materials and publicservice ads featuring well-known library users to run in your newsletter and other campus publications (see sample on page 78).

- Collect "Libraries Change Lives" stories. It can be a rewarding activity. Offer prizes to those who share statements of 100 words or less about how libraries have made a difference in their lives. The Public Relations Department at Onondaga Community College in Syracuse, New York, placed articles in both student and community newspapers and published an inspiring booklet of testimonials collected by the library. Those who send copies of 25 or more statements to the ALA Public Information Office will receive a free Microsoft Encarta Multimedia Encyclopedia.

- Reach out to the media. NLW adds an element of timeliness that can help place a story that might not be considered newsworthy at another time of year. Suggest a feature to your campus or community newspaper about your "Libraries Change Lives" winners. Create and publicize a list of questions answered by your staff ranging from the most challenging to the most common. Provide a series of colorful "Did you know. . . " factoids about the library's history, services, and use (e.g., "xxx students visited the library last year-more than attended all sporting events combined")

- Last, but not least, have fun. Hold a daily drawing for "Libraries Change Lives" tshirts, notepads, etc. Have staff answer the phone with the greeting "Happy National Library Week." Host a campuswide coffee break.

Library promotion and advocacy is a yearround effort, but National Library Week comes only once a year. Take advantage of it. And remember, if you don't celebrate, who will?

(Cont. on page 78) 


\section{Now get unlimited, low-cost access to the PAIS Database via leased tape}

For as low as $\$ 3,000$ per year, you can have unlimited access to the PAIS International Database, the premier bibliographic index to public and social policy issues.

\section{Economical, fixed-fee pricing.} With leased magnetic tapes, there's no need to worry about usage and teleconnect fees. Your users can search PAIS as often as they like, for as long as they like, all for one annual rate.

Flexibility and ease of use. PAIS is compatible with most OPACs. That means your users don't have to learn different search software, and you don't have to acquire new hardware

\section{Institution-wide availability. With}

PAIS International on your network, users in dorm rooms and offices across an entire campus or organization can access the database 24 hours a day.
A total information resource. The PAIS magnetic tape includes references to some 400,000 journal articles, government documents, statistical directories, monographs, conference reports and more. The database also references literature published worldwide in English, French, German, Italian, Spanish and Portuguese. Bibliographic records a Thesaurus File, and Periodical and Publisher Directories round out this unique resource. ISSN, ISBN, LC and Superintendent of Documents are included in the data.

Full telephone support. PAIS support is never more than a fast phone call away.

An annual subscription to PAIS on magnetic tape includes 12 monthly updates and complete documentation.

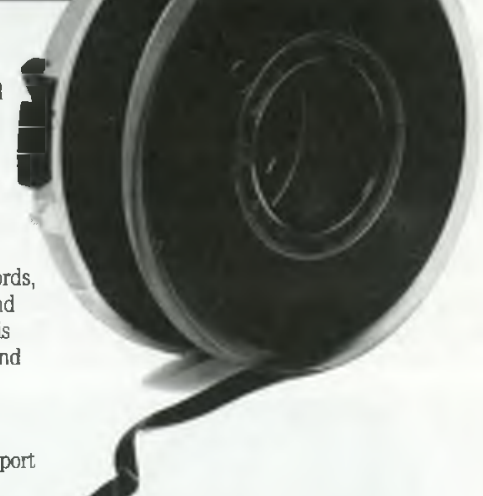

Backfiles also are available from 1972 to the present either as a whole file or in five-year units. For more information or a free sample tape, use the coupon below or call toll-free, 800-288-PAIS.
Please send me more information on PAIS Database tapes.

Please call me about receiving a sample tape and tape documentation. like PAIS
Nume
Institution
Address
Gity/State/ZIP
Phone Far
Public Affairs Information Service", Inc.
531 West 43rd Street, New York. NY 10036-4396
800-288-PAIS, 212-736-6609 (in NYC)
Fix: $212-6432848$, e-mall: inquiries@pais.org 